\title{
SEDIMENTARY PROCESSES AND BURIED ICE PHENOMENA IN THE PRO-GLACIAL AREAS OF SPITSBERGEN GLACIERS
}

\author{
By M. J. HAMBreY
}

(Department of Earth Sciences, University of Cambridge, Downing Street, Cambridge CB2 3EQ, England)

\begin{abstract}
Observations at the snouts of several glaciers in Spitsbergen indicate that, between their present apparent limits and the moraines dating from the maximum Holocene extent of ice, wide areas of outwash deposits underlain by dead glacier ice occur. Such ice was visible at a number of localities. Indirect evidence of dead ice includes kettle-holes, collapse structures and, in one case, a subglacial melt stream emerging as a fountain within one such plain. Aufeis, formed in early winter, can sometimes also be preserved in the long term if covered by fluvio-glacial material The presence of such ice has implications for the interpretation of softsediment structures in glacigenic successions. Previously, many folds and faults have been interpreted as resulting from active ice overriding or pushing the sediment. Simple ablation beneath the sedimentary layer in question also gives rise to similar structures.
\end{abstract}

RÉsumé. Processus de sédimentation et phénomènes de glace enterrée dans les zones proglaciaires des glaciers du Spitsberg. L'observation des langues terminales de plusieurs glaciers du Spitsberg montre que de vastes zones de dépòts par l'eau recouverts par de la glace morte de glacier subsistent entre les limites actuelles apparentes des glaciers et les moraines datant du maximum holocène d'extension glaciaire. Une telle glace est visible en de nombreux endroits. Des preuves indirectes de glaces mortes sont apportées par des entonnoirs, des structures d'effondrement, et, dans un cas, par un écoulement d'eau de fusion sous-glaciaire qui surgit comme une fontaine dans une de ces plaines. Une congère formée au début de l'hiver, peut parfois être aussi préservée pour longtemps si elle est recouverte par du matériel

\section{INTRODUCTION}

This paper outlines characteristics of the proglacial areas of several Spitsbergen glaciers that previously have received little attention. During the course of geological investigations since 1977, the author has had the opportunity of observing previously little-documented processes operating on the fluvio-glacial outwash plains of several valley glaciers (Fig. la). These processes concern the behaviour of outwash streams, the burial of glacier ice, and the formation of Aufeis. Their significance relates to the sedimentology and stratigraphy of proglacial successions.

In general, the glaciers show no evidence of surging. Each of them has undergone slow but steady retreat from their maximum Holocene extents. In the late nineteenth century most glaciers were advancing (Garwood and Gregory, 1898) but by the beginning of the twentieth century many were already undergoing retreat (Stevenson, 1905). By the 1920's retreat was general (Wordie, 1921) and this pattern has been maintained to the present day. The snouts of glaciers terminating on land today are up to a few kilometres from their maximum Holocene limits, the intervening areas being sites of considerable fluvial activity.

\section{A MORAINE - FLUVIO-GLACIAL OUTWASH COMPLEX WITH BURIED ICE PHENOMENA}

The pro-glacial environment in Spitsbergen frequently reflects a complex interplay of glacial, fluvial, marine, and tidal processes. The pro-glacial area of Comfortlessbreen and Uversbreen in Engelskbukta is an excellent example. These two separate valley glaciers merge near their snouts and spread out into fluvio-glaciaire. La présence de ces glaces a des conséquences pour l'interprétation des structures à sédiments meubles dans la succession des épisodes glaciaires. Autrefois beaucoup de dépressions et de lacunes ont été intreprétées comme résultant de l'action d'une glace active chevauchant ou poussant le sédiment. La simple ablation sous le niveau sédimentaire en question donne aussi naissance à des structures semblables.

Zusammenfassung. Sedimentationsprozesse und verschüttete Eisbildungen in den Vorfeldern von Spitzbergen-Gletschern. Beobachtungen an den Zungen mehrerer Gletscher in Spitzbergen zeigen, dass weite Gebiete von fluviatilen Ablagerungen, unterlagert von Toteis, zwischen ihren derzeitigen, sichtbaren Grenzen und den Moränen, die vom Höchststand des Eises im Holozän stammen, vorkommen. Solches Eis war an einer Reihe von Stellen sichtbar. Der indirekte Nachweis für das Vorhandensein von Toteis stützt sich auf Kesselformen, Einbruchstrukturen und - in einem Fall - auf einen subglazialen Schmelzwasserstrom, der als Fontäne innerhalb einer solchen Ebene auftaucht. Aufeis, gebildet im Frühwinter, kann manchmal ebenfalls langfristig erhalten bleiben, wenn es mit fluvioglazialem Material zugedeckt wird. Das Vorhandensein solchen Eises führt zu Schwierigkeiten bei der Interpretation von weichen Ablagerungen in glazigenen Schichtfolgen. Früher wurden viele Verwerfungen und Falten als Ergebnis einer aktiven Eisüberfahrung oder -zusammenschiebung des Sediments gedeutet; doch führt einfache Ablation unter der jeweiligen Sedimentschicht zu ähnlichen Strukturen.

a broader valley. Comfortlessbreen terminates partly in the sea, into which it calves; Uversbreen ends entirely on land (Fig. 1b). The principal characteristics of the pro-glacial area are as follows.

\section{Outer moraine complex}

The outer moraine complex of Comfortlessbreen attains a height of about $30 \mathrm{~m}$ above plain level and is 1-2 km from the present glacier limits. The complex overlies a raised-beach terrace which is preserved outside the moraines. Sand and well-rounded pebbles comprise the outer part of the moraines and evidently represent pushed-up raised-beach material. Towards the glacier, there is a transition to a facies of mainly crudely bedded clay with dispersed stones, in which some more silty horizons also occur. Bivalve shells, mostly broken, some of which are encrusted with crustaceans, indicate that this material was pushed up from the sea bed. Coralline algae also encrust some of the stones in this reworked waterlain till, further suggesting a marine origin prior to the till being raised into a prominent ridge.

Outwash areas between outer moraines and glacier margins

Two main areas, partly separated by a moraine ridge and a dolostone rock outcrop, can be identified (Fig. 1b) between the outer moraine and Comfortlessbreen. One of these areas is covered by extensive raised beaches, comprising reworked till and fluvio-glacial material, pitted with large, deep depressions, the largest over $200 \mathrm{~m}$ across, which may represent kettle-holes formerly occupied by dead ice.

The main melt-water stream from Uversbreen, issuing from along its northern margin, divides, one branch forming a braided-channel system outside the 

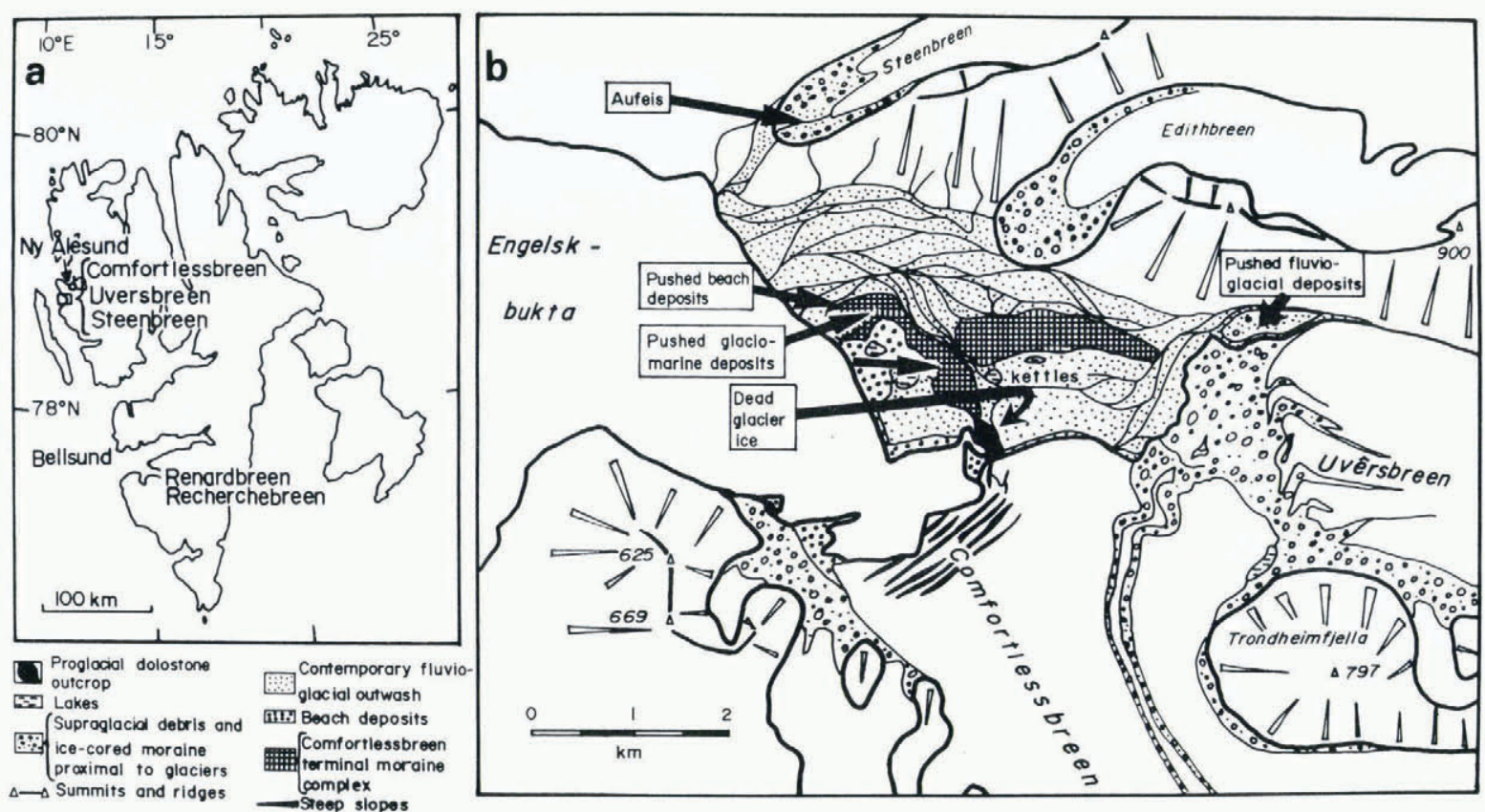

Fig. 1. (a) Svalbard, with localities mentioned in the text. (b) Sketch map of the pro-glacial area of Comfortiessbreen, Uversbreen, and Steenbreen.

Comfortlessbreen moraines, the other occupying a discrete channel running along and undercutting the front of Comfortlessbreen. The latter stream flows over the dolostone outcrop, beyond which bedded fluvio-glacial sands and gravel have been deposited as the stream enters the sea. These sediments are partly cross-bedded, and have been folded as a result of soft-sediment deformation as stagnant ice melted below them.

The greater part of the other area, a large flat outwash plain also between Comfortlessbreen and its moraines, comprises principally well-sorted sands with lesser amounts of clay, silt and gravel. A smal outlet stream runs across this plain and cuts through it to a depth of $1-2 \mathrm{~m}$. Much silt on this plain is thixotropic and quicksands are widespread. Sedimentary structures include clear parallel stratification, trough cross-bedding, contorted bedding, and normal faults with displacements of several centimetres. The sediments overlie an extensive area of thick ice that is exposed only in the stream section (Fig. 2). The crystal structure of this ice is

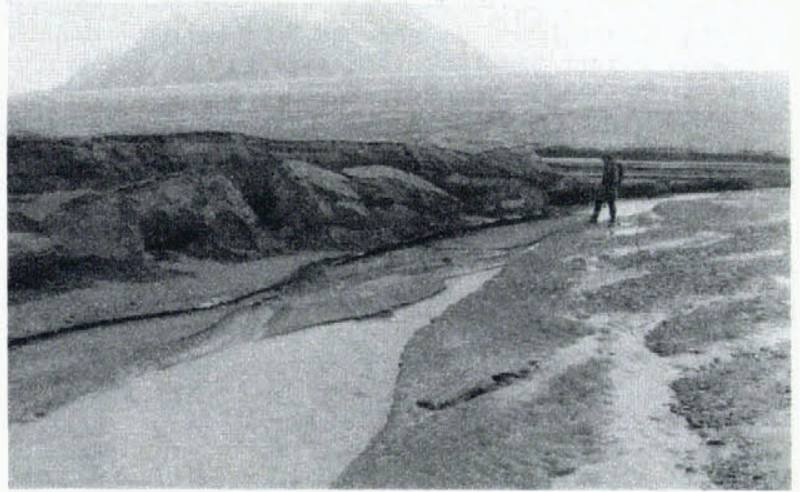

Fig. 2. Stratified fluvio-glacial sands and gravels overlying dead glacier ice with the apparent snout of Comfortlessbreen beyond. Dead ice is visible immediately left of the man and continues to the left under all the sediments exposed in the stream section. Glacier ice also underlies the small strean which here is flowing back towards the glacier. Photograph taken in late August 1981. characteristic of dead glacier ice. A few kettleholes suggest that the whole of the plain is underlain by dead glacier ice. Only a few descriptions of faults in fluvio-glacial sediments arising from melting of underlying ice have been published; examples have been given by Boulton (1972) from Prins Karls Forland, Spitsbergen, Shaw (1972) from Shropshire, England, and Selsing (1981) from Denmark.

\section{AUFEIS AND BURIED GLACIER ICE ON AN OUTWASH PLAIN}

Aufeis or naled ice is a phenomenon characteristic of the outwash plains of many Spitsbergen glaciers (e.g. Baranowski, 1977, 1982; Cegla and Kozarski, 1977 ; Migala and Sobik, 1982). It is characterized by horizontal stratification and stacks of long, vertically orientated crystals comprising each layer. Usually, such ice disappears by mid-summer, but, under favourable conditions, it may persist for a considerable time. For example, if Aufeis is buried by fluvioglacial outwash material, it may survive over the summer and give rise to hummocky landforms and depressions as the ice melts differentially; Cegla and Kozarski (1977) and Baranowski (1977) described such features below Gasbreen and elsewhere in southern Spitsbergen.

A complex association of Aufeis, glacier ice, and fluvio-glacial deposits was observed in the outwash plain below the small glacier Steenbreen in Engelskbukta, western Spitsbergen.

The outwash plain lies at a considerable angle (up to c. $10^{\circ}$ ) and in late summer (26 August) 1981 a large expanse of Aufeis interbedded with the snowpack still covered much of the plain (Fig. 3). The presence of this ice clearly had had a marked effect on the drainage; instead of the usual braided stream development, melt-water streams had formed deep, vertical-walled channels in the Aufeis itself and in a variety of underlying deposits. Some channels had been abandoned.

One channel section (Fig. 4) in the lower part of the outwash plain revealed a $3 \mathrm{~m}$ layer of clean Aufeis, comprising not only the typical long vertical crystals but also laminated granular ice perhaps formed by recrystallization of vertical crystals or by freezing of slush. Beneath the Aufeis lay $1 \mathrm{~m}$ of well-to poorly sorted sands, gravels, and boulders, representing 


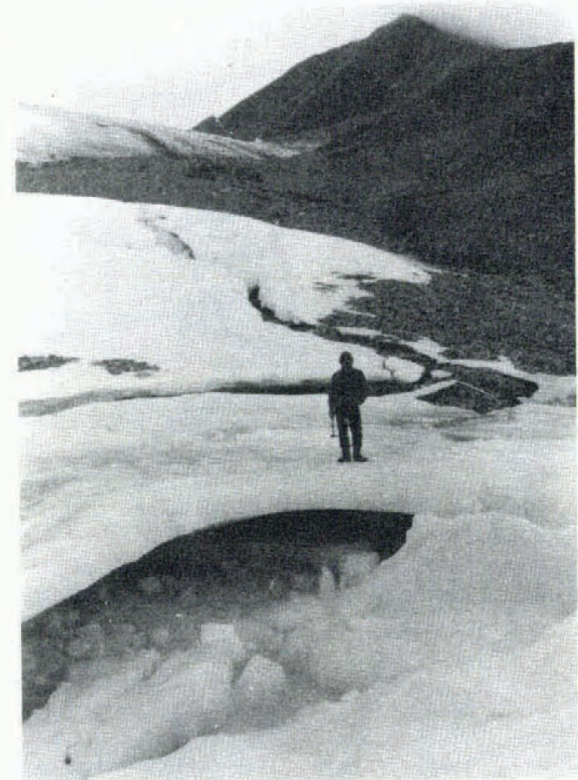

Fig. 3. Aufeis below the snout of Steenbreen (top left), 26 August 1981. In the foreground a cavern beneath the Aufeis has partially collapsed into a now-frozen pond. Beyond, a large channel has been cut through the Aufeis by melt water from the glacier but is now abandoned.

various degrees of reworking of till by melt waters. Then followed clean glacier ice with a characteristic irregular crystal structure, foliation, folding, and elongated air bubbles formed by internal deformation of the glacier before stagnation.

In the middle part of the outwash plain, channelling had exposed three distinct Aufeis layers, separated by fluvio-glacial outwash sediments. Also in the same area, a cavern of arched Aufeis with crystals $30 \mathrm{~cm}$ long, revealed frozen melt water and gravel beneath; presumably a stream passing beneath caused melting from below but the arching is a puzzle. W.H. Theakstone (personal communication, 1983) noted a similar phenomenon that he observed at the eastern side of Austre Lovénbreen in Kongsfjorden on 29 July 1968. There, one section of Aufeis composed of vertically orientated crystals $40-50 \mathrm{~cm}$ long was arched over a horizontal distance of c. $4 \mathrm{~m}$ and to a height of $2 \mathrm{~m}$. Concentric collapse over a stream was associated with the arching. He tentatively suggested that this arching might indicate pushing and buckling by the glacier as it advanced in winter. Whether multiple Aufeis layers, separated by fluvio-glacial deposits, are unique is not known but it is not unusual for the feature to survive into late summer in other parts of Spitsbergen. Aufeis usually forms in early winter when water continues

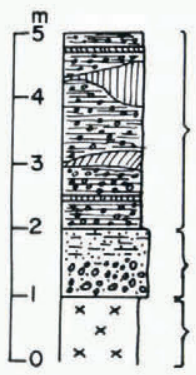

Aufeis complex: 1ayers and lenses of vertical or slightly

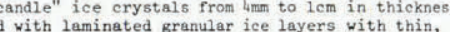
fine, firn-like crystals between

Fluvioglacial deposits: weakly stratified sand and grave Glacier ice: deformed coarsely crystalline ice (crystals
several cm long and of irregular slape), with folding

Fig. 4. Roughly measured section through an Aufeis layer, underlain successively by fluvio-glacial deposits and dead glacier ice, Steenbreen, 26 August 1981. Slope angle is $5^{\circ}$.

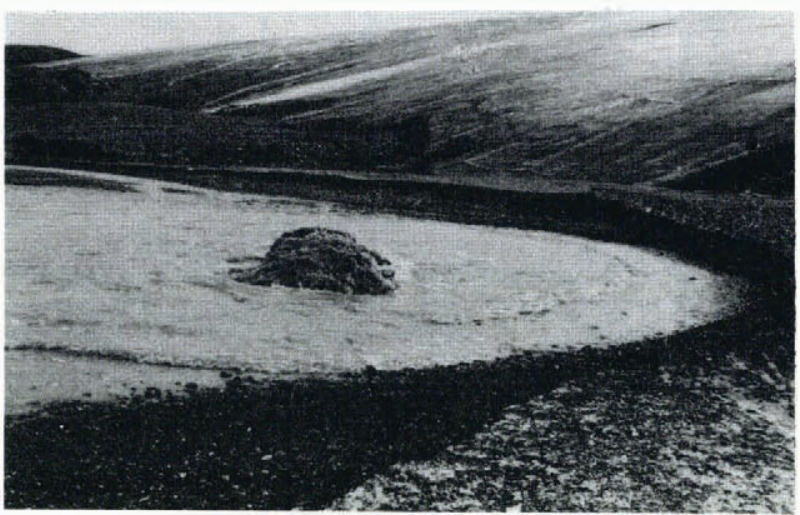

Fig. 5. Fountain approximately $2 \mathrm{~m}$ high mising through the outwash plain c. $60 \mathrm{~m}$ from the apparent snout of Renardbreen, $28 \mathrm{July}$ 1978. At the time this was the main discharge from the glacier and water was visibly eroding the surrounding outwash deposits and tili.

to flow from the glacier, although the air temperature has already fallen below freezing. In late September and early 0ctober 1980 , rain followed by temperatures of $-15^{\circ} \mathrm{C}$ resulted in ice formation on the ground at $\mathrm{Ny}-\AA \mathrm{l}$ esund just to the north (personal communication from M.F. Chantry, 1981). Such conditions may have been particularly favourable to Aufeis development at Steenbreen.

\section{AN OUTWASH PLAIN FOUNTAIN}

An unusual indication of glacier ice buried beneath an outwash plain was observed near the snout of Renardbreen, a glacier terminating partially in the sea but mainly on a gently sloping reworked till plain. On 28 July 1978, a vigorous stream issued under high pressure about $60 \mathrm{~m}$ from the apparent gently sloping margin of the glacier, on the plain of outwash gravels between two rock outcrops recently exposed by the retreating ice (Fig. 5). The fountain reached a height of $2 \mathrm{~m}$. After 3 days, two of them mild, wet, and windy, the fountain had built up an oblique cone of gravel about $2 \mathrm{~m}$ high, while the issuing water was visibly eroding the surrounding gravels and till lodged behind one of the rock outcrops. At the time, the discharge from this stream was far greater than that from any other pro-glacial stream; clearly, for a time it was the main outlet of melt water from the glacier.

The fountain appeared to be a new phenomenon when observed in late July 1978. In 1977, the main outwash stream of Renardbreen discharged from beneath the visible ice near the true left margin, forming a large outwash plain extending over lodgement till and fluted moraine. It is not known whether the discharge from the glacier reverted to a more normal position after our 1978 visit.

Water issuing from a glacier snout under high pressure is not unusual, nor are fountains at the glacier surface. For example, Baranowski (1973, 1975) described water-spouts up to $60 \mathrm{~m}$ high originating from cracks in Werenskiöldbreen, south-west Spitsbergen. However, the phenomenon described above is unique and can only be explained by the outwash-plain debris rather thinly covering buried glacier ice, in which englacial or subglacial channels still were connected with the visible part of the glacier. The absence of the fountain in 1977 might indicate blockages of these channels which subsequently were flushed out.

The outwash plain of the nearby Recherchebreen includes buried glacier ice beneath $1.5 \mathrm{~m}$ of outwash gravels, and some collapse features are present. Although buried glacier ice was not seen at Renardbreen, all the available evidence suggests that it does exist there, as elsewhere. 


\section{IMPLICATIONS OF BURIED ICE}

The aforementioned glaciers are typical of many in Svalbard that terminate on flat outwash plains close to sea-level. Observations indicate that many outwash plains within the limits of the maximum postglacial advance are underlain by dead ice of unknown thickness, as evidenced by kettle-holes, collapse structures and, occasionally, stream sections cutting through to the ice level. The Renardbreen fountain is a further but unusual indicator of buried ice. Despite the presence of such ice, the active glacier margins appear to be well defined (Fig. 5). Dynamically, this dead ice is isolated from the main glacier, although the Renardbreen example suggests that englacial or subglacial drainage channels can be continuous.

In any subsequent advance this ice could play a significant role, especially as large ice masses buried by fluvio-glacial deposits might become rejuvenated relatively quickly. Buried Aufeis, of the type observed at Steenbreen, where more than one horizon is preserved by outwash deposits, could also influence the behaviour of an advancing glacier. In effect, areas like this represent accumulation areas at the glacier snout. Crystallographically, buried dead glacier ice and Aufeis are easily distinguished but the difference may soon be obscured when recrystallizing as the ice becomes dynamically active. A glacier advance incorporating stratified fluvioglacial sediments and Aufeis could give rise to the bed-parallel debris layers seen in the basal parts of some glaciers.

The presence of widespread buried ice also has implications for interpreting sedimentary structures in Quaternary and pre-Pleistocene glacigenic successions. Soft-sediment deformation structures such as faults and folding are usually inferred to be the result of glacio-tectonic effects such as overriding or pushing of soft sediment by an advancing glacier. However, some authors have explained normal faults as the result of collapse of sediments as buried ice melts (Boulton, 1972; Shaw, 1972; Selsing, 1981). Not only faults but also folds and contorted bedding may be the result of ablation below a fluvio-glacial or till plain of old buried glacier ice. Faulting and contorted bedding are well developed, for example, in sediments overlying the dead ice in front of Uversbreen and Comfortlessbreen.

\section{CONCLUSIONS}

Aufeis, which is widely developed in the proglacial areas of many Spitsbergen glaciers, can be preserved by burial under fluvio-glacial sediments along with considerable bodies of dead glacier ice. The presence of buried ice is indicated by pitted and hummocky outwash plains, and in one case by a melt-water fountain. Ablation of such ice beneath fluvio-glacial and glacial materials may lead to the development of synsedimentary folding and normal faulting. Similar structures in older glacial successions may be explained in this way rather than the more usual one of glacio-tectonic deformation.

\section{ACKNOWLEDGEMENTS}

The author is grateful to Mr W.B. Harland for being able to participate in the Cambridge Spitsbergen Ex- peditions of 1977-79 and 1981-82, during which these observations were made. The organization provided logistic and some financial support, while the 1981 and 1982 seasons were supported by the U.K. Natural Environment Research Council. Thanks are also due to J.A. Dowdeswell and W.H. Theakstone for comments on the manuscript. These observations were made incidentally during studies of late Precambrian stratigraphy.

\section{REFERENCES}

Baranowski, S. 1973. Geyser-1ike water spouts at Werenskioldbreen, Spitsbergen. Union Geodésique et Geophysique Intermationale. Association Intemationale d'Hydrologie Scientifique. Commission de Neiges et Glaces. Symposium on the Hydrology of Glaciers, Cambridge, 7-13 September 1969, p. 131-33. (Publication No. 95 de 1 'Association Internationale d'Hydrologie Scientifique.)

Baranowski, S. 1975. Glaciological investigations and glaciomorphological observations made in 1970 on Werenskiold glacier and in its forefield. Acta Universitatis Wratislaviensis (Wroclaw), No. 251, p. 69-94. (Results of Investigations of the Polish Scientific Spitsbergen Expeditions, 1970-1974, Vol. 1.)

Baranowski, S. 1977. Naled type of ice in front of some Spitsbergen glaciers. Acta Universitatis Wratislaviensis (Wroclaw), No. 387, p. 85-89. (Results of Investigations of the Polish Scientific Spitsbergen Expeditions, 1970-1974, Vol. 2.)

Baranowski, S. 1982. Naled ice in front of some Spitsbergen glaciers. Joumal of Glaciology, Vol. 28, No. 98, p. 211-14.

Boulton, G.S. 1972. Modern Arctic glaciers as depositional models for former ice sheets. Joumal of the Geological Society of London, Vol. 128, Pt. 4, p. 361-93.

Cegla, J., and Kozarski, S. 1977. Sedimentary and geomorphological consequences of the occurrence of naled sheets on the outwash plain of the Gas Glacier, Sörkappland, Spitsbergen. Acta Universitatis Wratislaviensis (Wroclaw), No. 387, p. 63-84. (Results of Investigations of the Polish Scientific Spitsbergen Expeditions, 1970-1974, Vol. 2.)

Garwood, E.J., and Gregory, J.W. 1898. Contributions to the glacial geology of Spitsbergen. Quarterly Joumal of the Geological Society of London, Vol. 54, No. 214, p. 197-226.

Migala, K., and Sobik, M. 1982. Discovery of thermal springs in the Raudfjellet region, S.W. Spitsbergen. Polar Research (0slo, Norsk Polarinstitutt), 1982 , No. 2, p. 109-10.

Selsing, L. 1981. Stress analysis on conjugate normal faults in unconsolidated Weichselian glacial sediments from Brorfelde, Denmark. Boreas, Vol. 10, No. 3, p. 275-79.

Shaw, J. 1972. Sedimentation in the ice-contact environment, with examples from Shropshire (England). Sedimentology, Vol. 18, Nos. 1-2, p. 23-62.

Stevenson, J.J. 1905. Recent geology of Spitzbergen. Joumal of Geology, Vol. 13, No. 7, p. 611-16.

Wordie, J.M. 1921. Present-day conditions in Spitsbergen. Geographical Joumal, Vol. 58, No. 1, p. $25-49$. 